\title{
Impact of relative dose intensity of oxaliplatin in adjuvant therapy among stage III colon cancer patients on early recurrence: a retrospective cohort study
}

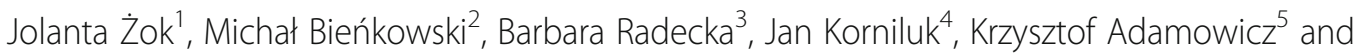
Renata Duchnowska ${ }^{4 *}$

\begin{abstract}
Background: Oxaliplatin-based therapy with FOLFOX-4 or CAPOX administered over 6 months remains the standard adjuvant treatment for stage III colon cancer (CC) patients. However, many patients experience dose reduction or early termination of chemotherapy due to oxaliplatin toxicity, which may increase the risk of early recurrence. The objective of this study was to analyze the relationship between the relative dose intensity of oxaliplatin (RDI-O) and early recurrence among stage III CC patients.

Methods: The study included 365 patients treated at five oncology centers in Poland between 2000 and 2014. Survival analysis was performed using the Kaplan-Meier method. Univariate analysis was performed using the Cox proportional hazard model; multivariate analysis was performed with the stepwise forward approach. For all analyses the a level of 0.05 was employed.

Results: The median follow-up was 51.8 months (range 8.2-115.1). Early recurrence $<36$ months after surgery occurred in 130 patients (37.8\%). In this group 51 (39.2\%) and 87 (66.9\%) of patients were low and high-risk, respectively. Receipt $<60 \%$ of RDI-O was associated with early recurrence within 18 months after surgery $(\mathrm{OR}=2.05$; 95\%Cl: $1.18-3.51 ; p=0.010)$, especially in low-risk group ( $\mathrm{HR}=1.56$ (95\% Cl: $0.96-2.53), p=0.07)$. In the multivariate analysis early recurrence was correlated with grade $(\mathrm{OR}=2.47 ; 95 \% \mathrm{Cl}: 1.25-4.8 ; p=0.008), \mathrm{pN}(\mathrm{OR}=2.63 ; 95 \% \mathrm{Cl}$ : $1.55-4.54 ; p<0.001)$, the number of lymph nodes harvested (OR $=0.51 ; 95 \% \mathrm{Cl}: 0.29-0.86 ; p=0.013)$ and RDI-O $(\mathrm{OR}=1.91 ; 95 \% \mathrm{Cl}: 1.06-3.39 ; p=0.028)$. The early vs. late recurrence negatively correlated with OS regardless of the RDI-O (HR=22.9 (95\%Cl: 13.9-37.6; $p<0.001)$.

Conclusions: $\mathrm{RDI}-\mathrm{O}<60 \%$ in adjuvant therapy among stage III CC (especially in low-risk group) increases the risk of early recurrence within 18 months of surgery. Patients with early recurrence showed worse overall survival regardless of the RDI-O.
\end{abstract}

Keywords: Colon cancer, Adjuvant chemotherapy, Oxaliplatin, Cumulative dose, Relative dose intensity

\footnotetext{
* Correspondence: rdtt@wp.pl

${ }^{4}$ Department of Oncology, Military Institute of Medicine, 04-141 Warsaw, Poland

Full list of author information is available at the end of the article
}

(c) The Author(s). 2021 Open Access This article is licensed under a Creative Commons Attribution 4.0 International License, which permits use, sharing, adaptation, distribution and reproduction in any medium or format, as long as you give appropriate credit to the original author(s) and the source, provide a link to the Creative Commons licence, and indicate if changes were made. The images or other third party material in this article are included in the article's Creative Commons licence, unless indicated otherwise in a credit line to the material. If material is not included in the article's Creative Commons licence and your intended use is not permitted by statutory regulation or exceeds the permitted use, you will need to obtain permission directly from the copyright holder. To view a copy of this licence, visit http://creativecommons.org/licenses/by/4.0/ The Creative Commons Public Domain Dedication waiver (http://creativecommons.org/publicdomain/zero/1.0/) applies to the data made available in this article, unless otherwise stated in a credit line to the data. 


\section{Background}

Significant advances have been made in the study of colon cancer (CC) in the last few years. In patients with stage III CC, oxaliplatin and fluoropyrimidine-based chemotherapy is currently the standard of therapy in the adjuvant setting [1-6]. Three prospective phase 3 trials: MOSAIC (Multicenter International Study of Oxaliplatin/5-Fluorouracil, Leucovorin in the Adjuvant Treatment of Colon Cancer), NASBP-C07 (National Surgical Breast and Bowel Project) and NO16968 (XELOXA Trial) showed improvements in prolonged disease-free time (DFS) and overall survival (OS), especially in younger patients under 65 years [1-6]. Similar efficacy, with better tolerability, has been demonstrated for capecitabine in the oxaliplatin regimen (CAPOX) [7]. The intended dose of oxaliplatin is usually reported as part of the design of clinical studies, but the administered dose is often reduced due to chemotherapy side effects such as myelotoxicity or peripheral neuropathy, which may increase the risk of early recurrence [1-6]. In colorectal cancer (CRC) patients, $60-80 \%$ of recurrences become apparent within the first 2 years of curative surgery and $90 \%$ within the first 4 years [8-10]. The factors affecting early and late recurrence in CRC may differ among stage and primary tumour sites $[8,10,11]$. The objectives of this study were to analyze the relationship between the relative dose intensity of oxaliplatin (RDI-O) in the adjuvant setting and early recurrence in stage III CC patients.

\section{Methods}

\section{Study population}

The study group included 365 stage III colon cancer patients of Caucasian race, age 18 or older, who underwent radical surgical treatment followed by adjuvant chemotherapy with fluoropyrimidine and oxaliplatin. The patients were diagnosed and treated between 2000 and 2014 in five oncology centers in Poland. The exclusion criteria included: rectal tumours (as defined by the presence of the inferior pole of the tumour below the peritoneal reflection ( $<15 \mathrm{~cm}$ from the anal margin), unclear resection margins (residual tumour at the primary site: R1 or R2), inability to start adjuvant chemotherapy, and incomplete medical records. This study was approved by the Bioethics Committee of the Medical Chamber in Opole (Agreement No. 245/2017). All data were coded to secure full protection of personal information, therefore patient consent was not sought. All research was performed in accordance with relevant guidelines and regulations.

\section{Study treatment and procedures}

The adjuvant chemotherapy included regimens with oxaliplatin and fluoropyrimidine FOLFOX-4 or CAPOX used for 6 months. For each regimen the number of cycles, the duration of treatment, the cumulative dose (CD) and RDI-O are given. The primary tumour staging was performed in accordance with the seventh version of the TNM classification, developed by the American Joint Committee on Cancer (AJCC) and International Union for the Fight against Cancer (IUCC) [12]. The assessment of the adverse events (AEs) severity was based on the classification developed by the National Cancer Institute (NCI-National Cancer Institute) - Terminology Criteria for Adverse Events (CTCAE), version 4 [13]. All AEs reported in medical records during the treatment period or within 30 days after the last chemotherapy cycle are listed. Safety analyses were done for patients who received at least one dose of treatment. Patients may have had more than one AE. The manuscript was prepared according to the STROBE guidelines [14]. Follow-up was measured from adjuvant chemotherapy initiation until death or the last follow-up information. DFS was defined as the period between chemotherapy initiation and disease recurrence (local or distant), while OS was defined as the period between chemotherapy initiation and death (irrespective of the cause). Thirty-six months was used as the cut off $(<36$ vs $\geq 36)$ to define early and late recurrence. RDI represents the ratio of the amount of a drug actually administered to the amount planned for a fixed time period, according to formula: $[\mathrm{DDI} / \mathrm{SDI}] \times 100 \%$. DDI (delivered dose intensity) is delivered total dose (in $\mathrm{mg} / \mathrm{m}^{2}$ )/standard time to complete chemotherapy (in days) and SDI (standard dose intensity) is standard total dose (in $\mathrm{mg} / \mathrm{m}^{2}$ )/actual time to complete chemotherapy. Imputation was used for missed cycles (in days) [15].

\section{Statistical design}

The statistical analysis was performed using the R statistical software (version 4.0.0) [16]. The normality of distribution was assessed using the Shapiro-Wilk test. Due to the lack of normally distributed data, the comparison between the two groups was performed using the MannWhitney $U$ test, while the comparison between multiple groups was performed using the Kruskal-Wallis test and the post-hoc Dunn test with the Benjamini-Hochberg correction for multiple testing [17]. The data were visualized with box-plots. The RDI-O cut-off was selected based on its association with DFS and OS. Survival analysis was performed using the Kaplan-Meier method [18]. Univariate analysis was performed using the Cox proportional hazard model; multivariate analysis was performed with the stepwise forward approach. Similarly, logistic regression analysis was performed for 12month, 18-month and 36-month DFS, while the multivariate analysis employed the stepwise forward approach. For all analyses an $\alpha$ level of 0.05 was employed. 


\section{Results}

\section{Study population}

The study group included 365 stage III colon cancer patients: 176 females (48.2\%) and 189 males (51.8\%) (Table 1). The mean age at diagnosis was 61.2 years (range 25-80 years), 176 (48.2\%) patients were 63 years and $15.3 \%$ above 70 years. There were 176 patients $(48.2 \%)$ with high risk (pT4 and/or pN2) and 189 (51.8\%) with low risk (pT1-3 and pN1) stage III CC. The mean number of harvested lymph nodes was 13.2 (range 1-50). Left and right-sided primary tumours was 203 (55.6\%) and 161 (44.1\%), respectively. Most patients did not have diabetes at the time of diagnosis 325 (89\%), and the median body mass index (BMI) was 26.4 (range 15.6-44). Other baseline clinical and pathology characteristics are summarized in Table 1.

\section{Treatment duration and safety}

The median follow-up was 51.8 months (range 8.2115.1). The majority of patients received FOLFOX-4 (336 patients; 92\%) and 29 patients (8\%) received CAPOX. The mean number of chemotherapy cycles was 10.2 (standard deviation 2.76). Two hundred and nine (57.3\%), 45 (12.3\%) and 31 (10\%) patients received 12, 6 and $<6$ cycles, respectively. The distribution of chemotherapy cycles was well balanced between clinical stages IIIA $\left(\mathrm{pT}_{1-2} \mathrm{~N}_{1 \mathrm{a}-\mathrm{c}} / \mathrm{pT}_{1} \mathrm{~N}_{2 \mathrm{a}}\right)$, IIIB $\left(\mathrm{pT}_{3-4 \mathrm{a}} \mathrm{N}_{1 \mathrm{a}-\mathrm{c}} / \mathrm{pT}_{2-3} \mathrm{~N}_{2 \mathrm{a}} /\right.$ $\mathrm{pT}_{1-2} \mathrm{~N}_{2 \mathrm{~b}}$ ), IIIC ( $\left.\mathrm{pT}_{4 \mathrm{a}} \mathrm{N}_{2 \mathrm{a}} / \mathrm{pT}_{3-4 \mathrm{a}} \mathrm{N}_{2 \mathrm{~b}} / \mathrm{pT}_{4 \mathrm{~b}} \mathrm{~N}_{1-2}\right), p=0.47$.

The number of chemotherapy cycles was correlated with toxicity (Kruskal-Wallis-test $p=10^{-10}$ ). Seventyone patients (19.5\%) discontinued oxaliplatin-based chemotherapy due to adverse events. The median cumulative dose (CD) and RDI-O were $936.86 \mathrm{mg} / \mathrm{m}^{2}$ (range 84.03-1042.70; interquartile range, IQR: 763.78-1016.94 $\left[\mathrm{mg} / \mathrm{m}^{2}\right]$ ) and $82.32 \%$ (range 6.02-196.42, IQR: 61.3794.27), respectively. In the group of patients who completed 12 chemotherapy cycles, CD was $1012.33 \mathrm{mg} / \mathrm{m}^{2}$ (range 632.50-1042.70; IQR: 961.50-961.50 [mg/m²]) and RDI-O was $91.58 \%$ (range 30.16-196.42, IQR: 83.01-98.94). There was no difference between median $\mathrm{CD}, \mathrm{RDI}-\mathrm{O}$ and $\mathrm{pT}(p=0.46 ; p=0.07), \mathrm{pN}(p=0.85 ; p=$ $0.66)$, pTNM stage $(p=0.92 ; p=0.90)$ (Fig. 1$)$. The CD and RDI-O were correlated with therapy toxicity $(0=$ 0.03 and $p<0.01)$. Oxaliplatin-induced peripheral neuropathy (OXIPN): sensory and motor occurred in 212 (58.1\%), and 35 (9.6\%) patients, respectively. Severe (grade 3 ) and life-threatening (grade 4) OXIPN were diagnosed in $54(14.8 \%)$ and $9(2.5 \%)$ patients. There was no relationship between diabetes and the risk of OXIPN $(p=0.31)$.

\section{Activity and efficacy}

At the last follow-up 228 (62.5\%) patients were alive and 137 (37.5\%) had died. Median DFS was 43.86 months (range 0.79-113.42) and OS was 51.8 months (range $8.2-115.1)$. The number of cycles $\geq 6$ vs. $<6$ was not correlated with DFS and OS ( $\mathrm{HR}=0.68$ (95\% CI: 0.43-1.07) $p=0.09$ and $\mathrm{HR}=0.72$ (95\% CI: 0.43-1.18); $p=0.19$, respectively.

Early recurrence within 36 months after surgery occurred in 130 patients (36.6\%). The most common type of early relapse was distant metastases (100 patients; $76.9 \%$ ); rarely local recurrence (8 patients; $6.2 \%$ ) or both distant metastases and local recurrence (22 patients; $16.9 \%)$. The most common recurrence site was liver (74 patients; 60.7\%), followed by the lung (41 patients; $33.6 \%$ ), lymph nodes (27 patients; $22.1 \%$ ), other organs (16 patients; $13.1 \%$ ) and peritoneum (20 patients; $16.4 \%$ ). Bone and brain metastases were diagnosed in 6 (4.9\%) and $3(2.5 \%)$ cases.

The $\mathrm{RDI}-\mathrm{O}<60 \%$ was related with recurrence within 12 and 18 months $(\mathrm{OR}=2.04 ; 95 \% \mathrm{CI}: 1.08-3.78 ; p=$ 0.024 and $\mathrm{OR}=2.05 ; 95 \% \mathrm{CI}: 1.18-3.51 ; p=0.010)$ but not within 36 months $(\mathrm{OR}=1.50$; 95\%CI: 0.90-2.48; $p=$ 0.117) (Table 2), $\mathrm{HR}=1.39$ (95\%CI: 0.96-2.0, $p=0.08$ (Fig. 2).

The low-risk group recurrence within 12 and 18 months $(\mathrm{OR}=3.31 ; 95 \% \mathrm{CI}: 1.21-9.04 ; p=0.018$ and $\mathrm{OR}=2.73 ; 95 \% \mathrm{CI}: 1.16-6.37 ; p=0.020)$ and high-risk group $(\mathrm{OR}=1.72 ; 95 \% \mathrm{CI}: 0.71-3.96 ; p=0.209$ and $\mathrm{OR}=$ 2.06; 95\%CI: $0.96-4.42 ; p=0.062$ ) (Table 2); $\mathrm{HR}=1.56$ (95\%CI: $0.96-2.53$ ), $p=0.07$ (Fig. 3a) and $\mathrm{HR}=1.39$ (95\%CI: 0.79-2.44; $p=0.25$ ) (Fig. 3b).

In the univariate analysis, other factors which correlated with recurrence within 12 and 18 months were tumor grade $(\mathrm{OR}=2.82 ; 95 \% \mathrm{CI}$ : $1.39-5.53 ; p=0.003$ and $\mathrm{OR}=2.45 ; 95 \% \mathrm{CI}: 1.30-4.55 ; p=0.005), \mathrm{pT} \quad(\mathrm{OR}=3.03$; 95\% CI: $1.58-5.70 ; p=0.001$ and $\mathrm{OR}=1.93 ; 95 \% \mathrm{CI}$ : $1.07-3.68 ; p=0.027), \mathrm{pN}(\mathrm{OR}=1.78$; 95\% CI: 0.99-3.20; $p=0.051$ and $\mathrm{OR}=2.23 ; 95 \% \mathrm{CI}: 1.36-3.68 ; p=0.002$ ) (Table 2). In the multivariate analysis, recurrence within 12 and 18 months correlated with grade $(\mathrm{OR}=2.36$; 95\%CI: $1.09-4.9 ; p=0.025$ and $\mathrm{OR}=2.47$; 95\% CI: $1.25-$ $4.8 ; p=0.008), \mathrm{pT}(\mathrm{OR}=2.84 ; 95 \% \mathrm{CI}: 1.4-5.65 ; p=$ $0.003), \mathrm{pN}(\mathrm{OR}=1.93 ; 95 \% \mathrm{CI}: 1.03-3.63 ; p=0.041$ and $\mathrm{OR}=2.63$; 95\% CI: $1.55-4.54 ; p<0.001)$, the number of lymph nodes harvested (OR $=0.49 ; 95 \% \mathrm{CI}: 0.25-0.92$; $p=0.028$ and $\mathrm{OR}=0.51 ; 95 \% \mathrm{CI}: 0.29-0.86 ; p=0.013)$ and RDI-O (OR $=2.06$; 95\%CI: $1.03-4.01 ; p=0.036$ and $\mathrm{OR}=1.91$; 95\%CI: $1.06-3.39 ; p=0.028$ ) (Table 2).

In the multivariate analysis, recurrence within 36 months correlated with grade $(\mathrm{OR}=1.93$; $95 \% \mathrm{CI}$ : $1.02-$ $3.65 ; p=0.043)$, pT $(\mathrm{OR}=2.66 ; 95 \% \mathrm{CI}: 1.49-4.79 ; p=$ 0.001), $\mathrm{pN}$ (OR; 95\% CI: 1.53-4.01; $p<0.001$ ), and the number of lymph nodes harvested $(\mathrm{OR}=0.46 ; 95 \% \mathrm{CI}$ : $0.28-0.74 ; p=0.001$ ) (Table 2 ). The early vs. late recurrence negatively correlated with OS regardless of the RDI-O (HR = 22.9 (95\%CI: 13.9-37.6; $p<0.001)$. 
Table 1 Patient characteristics

Variables

n $365(100 \%)$

Age at diagnosis; years

Mean

62

Range

$<63$

189 (51.8\%)

$\geq 63$

$176(48.2 \%)$

$>70$

$56(15.3 \%)$

Gender

Female

$176(48.2 \%)$

Male

189 (51.8\%)

Body mass index $\left(\mathrm{kg} / \mathrm{m}^{2}\right)$

Median

26.4

Range

15 (6-44)

$\leq 18,5$

$13(3.6 \%)$

$18,5-24,9$

$128(35.1 \%)$

$\geq 25,0$

224 (61.4\%)

Diabetes mellitus

No

325 (89\%)

Yes

$40(11 \%)$

Histology

Adenocarcinoma not otherwise specified (NOS)

$304(83.3 \%)$

Mucinous adenocarcinoma

$54(14.8 \%)$

Adenocarcinoma of cylindrical cells

$2(0.5 \%)$

Signet ring adenocarcinoma

$2(0.5 \%)$

Adenosquamous carcinoma

$1(0.3 \%)$

Undifferentiated carcinoma

$2(0.5 \%)$

Histopathology grade (G)

G1 (well differentiated)

$33(9.0 \%)$

G2 (moderate differentiated)

$279(76.4 \%)$

G3 (poor differentiated)

$52(14.2 \%)$

No data

$1(0.3 \%)$

Primary tumor classification (pT)

$$
1
$$$$
2
$$$$
3
$$

$4 a$

$4 b$

$3(0.8 \%)$

$47(12.9 \%)$

$249(68.2 \%)$

$48(13.2 \%)$

$18(4.9 \%)$

Regional lymph nodes classification (pN)

$1 \mathrm{a}$

$106(29.0 \%)$

$1 b$

$119(32.6 \%)$

$1 \mathrm{C}$

$1(0.3 \%)$

1

$1(0.3 \%)$

$2 a$

$80(21.9 \%)$

$2 b$

$58(15.9 \%)$

Number of harvested lymph nodes 
Table 1 Patient characteristics (Continued)

\begin{tabular}{|c|c|}
\hline Variables & n $365(100 \%)$ \\
\hline$<12$ & $196(53.7 \%)$ \\
\hline$\geq 12$ & $165(45.2 \%)$ \\
\hline No data & $4(1.1 \%)$ \\
\hline \multicolumn{2}{|l|}{ Primary tumor location } \\
\hline Ceacum & $64(17.5 \%)$ \\
\hline Ascending colon & 49 (13.4\%) \\
\hline Hepatic flexure & $28(7.7 \%)$ \\
\hline Transverse colon & $20(5.5 \%)$ \\
\hline Splenic flexure & $22(6.0 \%)$ \\
\hline Descending colon & $14(3.8 \%)$ \\
\hline Sigmoid colon & $168(46.1 \%)$ \\
\hline \multicolumn{2}{|l|}{ Primary tumor location } \\
\hline Right colon & $161(44.1 \%)$ \\
\hline Left colon & $203(55.6 \%)$ \\
\hline No data & $1(0.3 \%)$ \\
\hline \multicolumn{2}{|l|}{ Surgery } \\
\hline Right hemicolectomy & $116(31.8 \%)$ \\
\hline Right hemicolectomy extended & $36(9.9 \%)$ \\
\hline Left hemicolectomy & $45(12.3 \%)$ \\
\hline Sigmoidectomy & $167(45.8 \%)$ \\
\hline Transversectomy & $1(0.3 \%)$ \\
\hline \multicolumn{2}{|l|}{ Adjuvant chemotherapy } \\
\hline FOLFOX-4 & $336(92 \%)$ \\
\hline CAPOX (XELOX) & $29(8 \%)$ \\
\hline \multicolumn{2}{|c|}{ CEA concentration before surgery; $\mathrm{ng} / \mathrm{ml}$} \\
\hline$<5$ & $96(26.3 \%)$ \\
\hline$\geq 5$ & $28(7.7 \%)$ \\
\hline No data & $241(66.0 \%)$ \\
\hline \multicolumn{2}{|c|}{ CEA concentration after surgery; $\mathrm{ng} / \mathrm{ml}$} \\
\hline$<5$ & $292(80.0 \%)$ \\
\hline$\geq 5$ & 33 (9.0\%) \\
\hline No data & 40 (11.0\%) \\
\hline
\end{tabular}

\section{Discussion}

The postoperative, oxaliplatin-based adjuvant chemotherapy for stage III CC patients demonstrated an improvement in patient outcome and has become the standard of care. In clinical trials, FOLFOX/CAPOX in adjuvant setting has been shown to cause a statistically significant improvement in DFS and OS over fluorouracil-based chemotherapy (4-7\% and 2-6\%, respectively) [1-6]. Further, in the MOSAIC and NO16968 study an improvement in OS was detected after a longer, approximately seven-year, follow-up [2, 6].

Unfortunately, adverse events caused by oxaliplatin often lead to premature termination of therapy and thus a reduction in the number of cycles or dose, and consequently the $C D$ and RDI [2-6]. In the MOSAIC, NASBP-C07 and NO16968 trials, approximately 30\% of patients receiving oxaliplatin did not complete the planned treatment due to adverse events, mainly burdensome OXIPN [1-3]. Similarly, in our study about 20 $\%$ of patients discontinued treatment, mainly due to OXIPN which occurred in various grades in 212 patients (58.1\%). Therefore, the number of adjuvant oxaliplatinbased chemotherapy cycles that may be enough in this group of patients remains an open question. Tsai et al. have shown that at least eight FOLFOX cycles are needed to have OS benefit, and seven to ensure DFS 

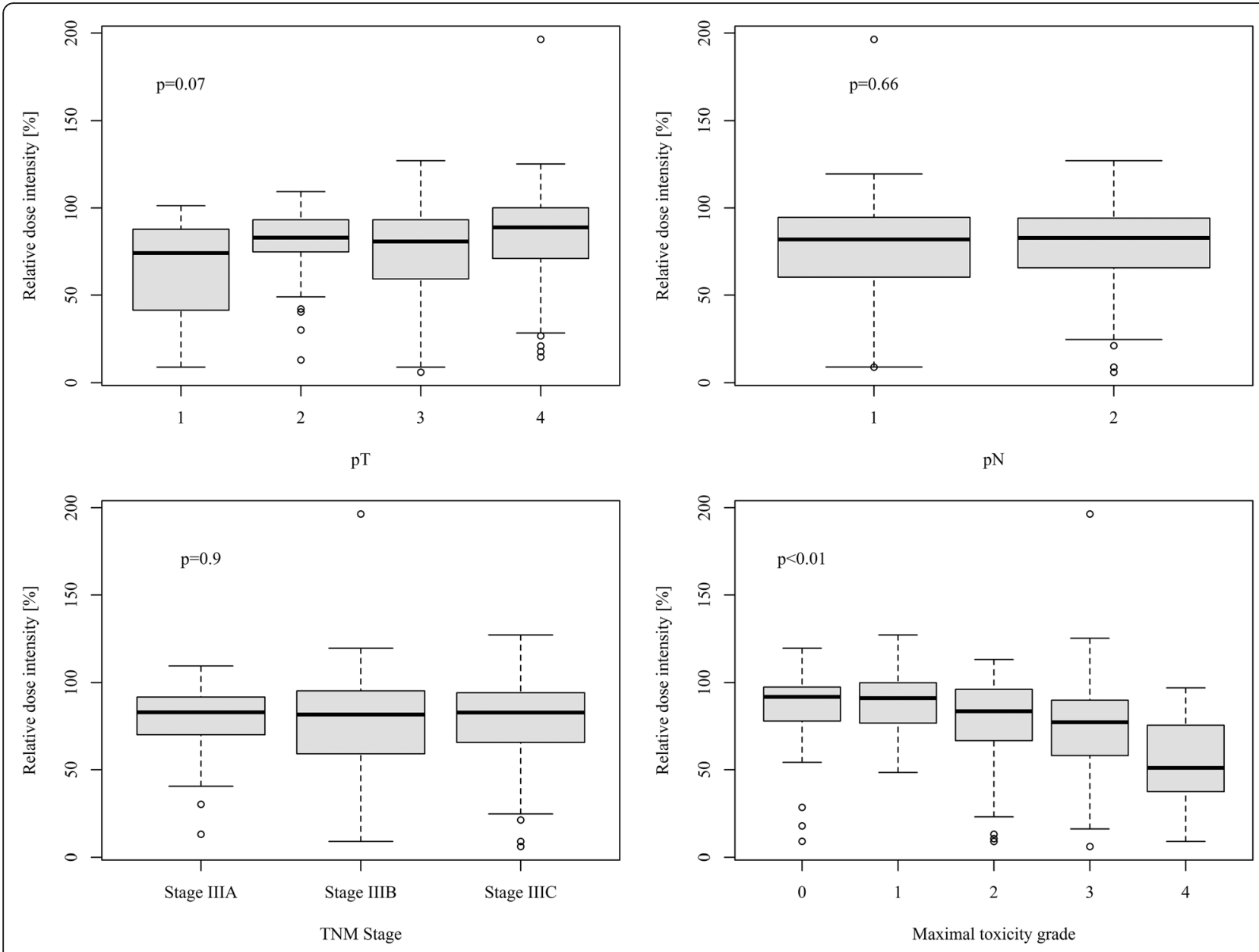

Fig. 1 Relative dose intensity for oxaliplatin and pT, pN, TNM and maximal toxicity grade

Table 2 Uni- and multivariate logistic regression for disease recurrence within 12, 18, and 36 months

\begin{tabular}{|c|c|c|c|c|c|c|}
\hline \multirow[t]{2}{*}{ DFS } & \multirow[t]{2}{*}{ Variable } & $\begin{array}{l}\text { Grade } \\
3 \text { vs } 2 \text { vs } 1\end{array}$ & \multirow[t]{2}{*}{$\begin{array}{l}\text { pT } \\
4 \text { vs } 3 \text { vs } 2 \text { vs } 1\end{array}$} & \multirow[t]{2}{*}{$\begin{array}{l}\text { pN } \\
2 \text { vs } 1\end{array}$} & \multirow[t]{2}{*}{$\begin{array}{l}\mathrm{N}^{\circ} \text { harvested } \\
\geq \text { vs }<12\end{array}$} & \multirow[t]{2}{*}{$\begin{array}{l}\text { RDI-O } \\
<60 \text { vs } \geq 60 \%\end{array}$} \\
\hline & & OR (95\% Cl); p & & & & \\
\hline \multirow[t]{2}{*}{$\begin{array}{l}12 \\
\text { months }\end{array}$} & Univariate analysis & $\begin{array}{l}2.82(1.39-5.53) ; \\
0.003\end{array}$ & $3.03(1.58-5.70) ; 0.001$ & $1.78(0.99-3.20) ; 0.051$ & $\begin{array}{l}0.59(0.32-1.06) ; \\
0.078\end{array}$ & $\begin{array}{l}2.04(1.08-3.78) ; \\
0.024\end{array}$ \\
\hline & $\begin{array}{l}\text { Multivariate } \\
\text { analysis }\end{array}$ & $\begin{array}{l}2.36(1.09-4.93) ; \\
0.025\end{array}$ & $2.84(1.40-5.65) ; 0.003$ & $1.93(1.03-3.63) ; 0.041$ & $\begin{array}{l}0.49(0.25-0.92) ; \\
0.028\end{array}$ & $\begin{array}{l}2.06(1.03-4.01) ; \\
0.036\end{array}$ \\
\hline \multirow[t]{2}{*}{$\begin{array}{l}18 \\
\text { months }\end{array}$} & Univariate analysis & $\begin{array}{l}2.45(1.30-4.55) ; \\
0.005\end{array}$ & $1.93(1.07-3.68) ; 0.027$ & $2.23(1.36-3.68) ; 0.002$ & $\begin{array}{l}0.61(0.37-1.00) ; \\
0.051\end{array}$ & $\begin{array}{l}2.05(1.18-3.51) ; \\
0.010\end{array}$ \\
\hline & $\begin{array}{l}\text { Multivariate } \\
\text { analysis }\end{array}$ & $\begin{array}{l}2.47(1.25-4.80) \\
0.008\end{array}$ & - & $\begin{array}{l}2.63(1.55-4.54)_{i}< \\
0.001\end{array}$ & $\begin{array}{l}0.51(0.29-0.86) ; \\
0.013\end{array}$ & $\begin{array}{l}1.91(1.06-3.39) ; \\
0.028\end{array}$ \\
\hline \multirow[t]{2}{*}{$\begin{array}{l}36 \\
\text { months }\end{array}$} & Univariate analysis & $\begin{array}{l}2.09(1.15-3.80) ; \\
0.015\end{array}$ & $\begin{array}{l}2.80(1.62-4.88) ;< \\
0.001\end{array}$ & 2.17 (1.39-3.39); 0.001 & $\begin{array}{l}0.62(0.40-0.96) ; \\
0.034\end{array}$ & $\begin{array}{l}1.50(0.90-2.48) ; \\
0.117\end{array}$ \\
\hline & $\begin{array}{l}\text { Multivariate } \\
\text { analysis }\end{array}$ & $\begin{array}{l}1.93(1.02-3.65) ; \\
0.043\end{array}$ & $2.66(1.49-4.79) ; 0.001$ & $\begin{array}{l}2.46(1.53-4.01) ;< \\
0.001\end{array}$ & $\begin{array}{l}0.46(0.28-0.74) ; \\
0.001\end{array}$ & - \\
\hline
\end{tabular}

DFS Disease free survival, $C$ C Confidence interval, OR Odds ratio, $p$ Pathological, $N^{\circ}$ Number, RDI-O Relative dose intensity of oxaliplatin 


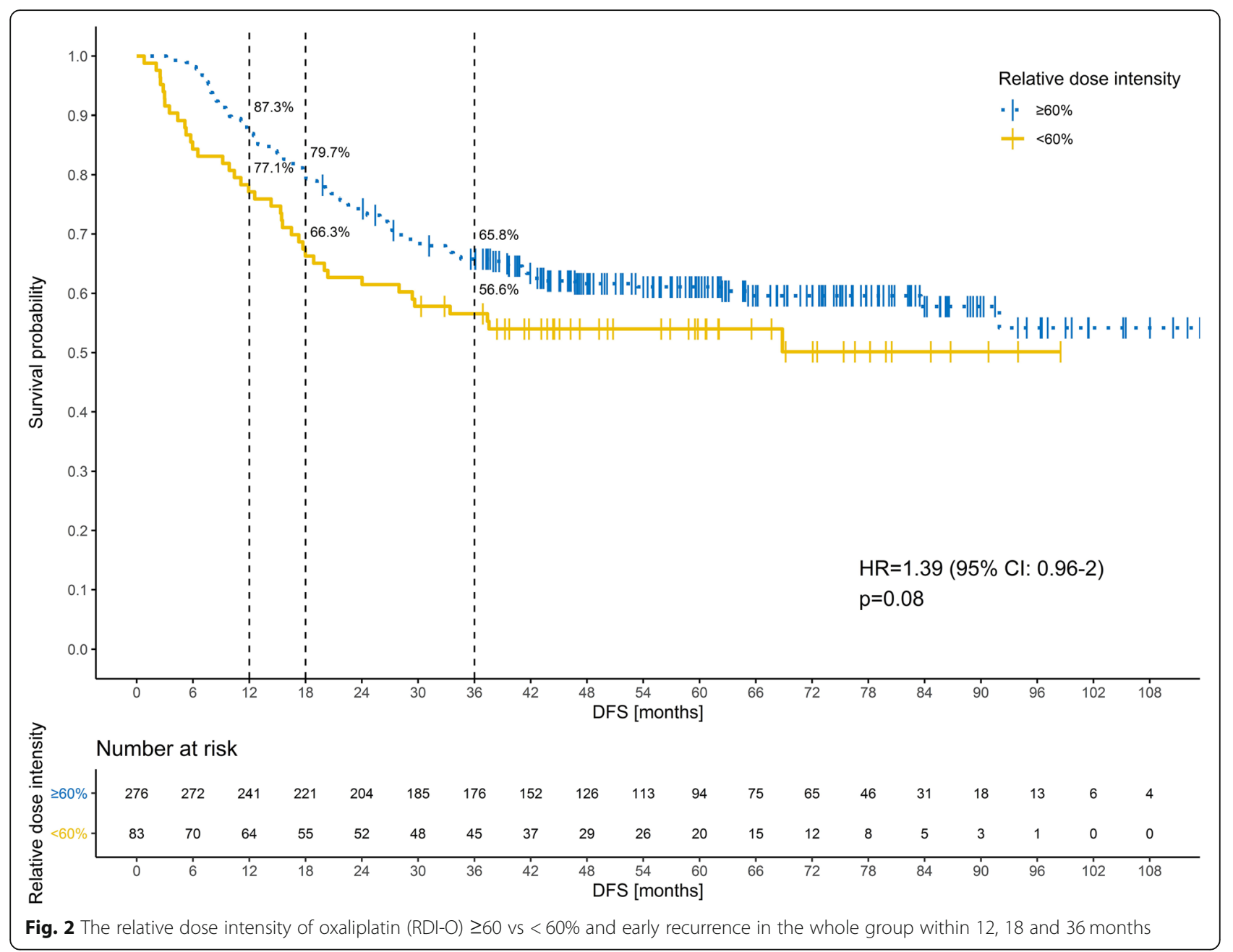

[19]. Moreover, in the International Duration Evaluation of Adjuvant Therapy (IDEA) project in stage III CC patients, the non-inferiority of FOLFOX/CAPOX regimens used for 3 vs. 6 months was not demonstrated [20-22].
However, in the lower risk group (pT1-3/N1), the 3month (4 cycles) CAPOX was as effective as the 6month $(8$ cycles) treatment and the 3 -year rate of DFS was 74.6 and $75.5 \%$, respectively [20-22]. Importantly,
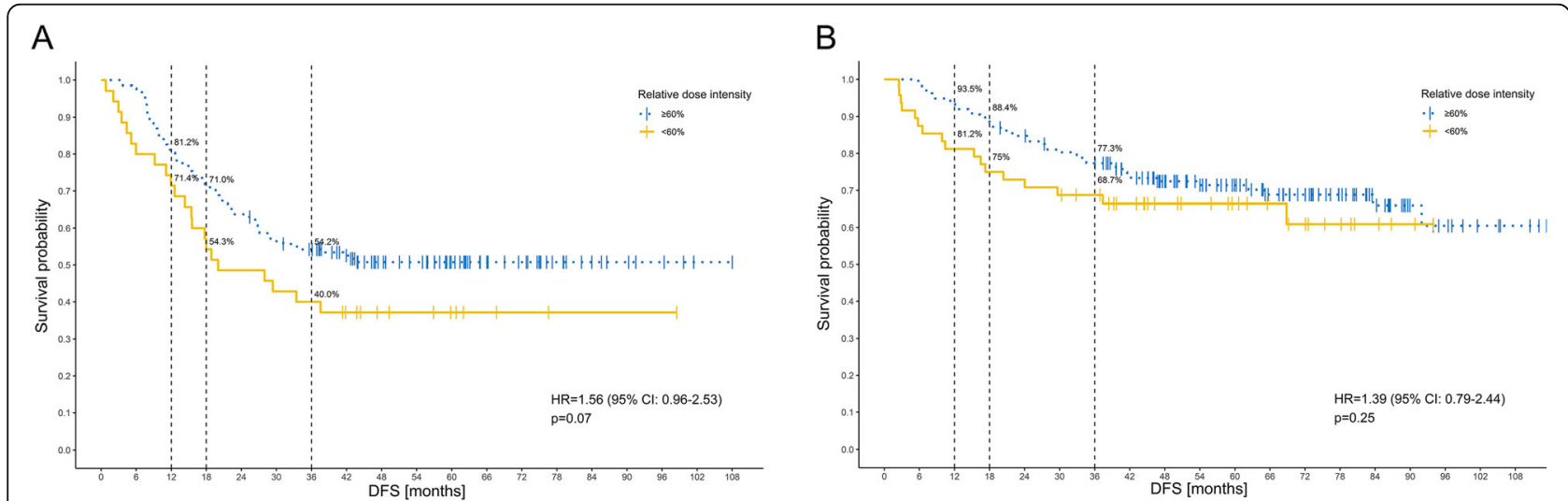

Fig. 3 The relative dose intensity of oxaliplatin (RDI-O) $\geq 60$ vs $<60 \%$ and early recurrence in low-risk (a) and high-risk (b) subgroups within 12,18 and 36 months 
the shorter treatment was associated with a lower risk of adverse events, including OXIPN.

To the best of our knowledge, the impact of RDI-O in adjuvant therapy among stage III colon cancer patients on early recurrence has not been systematically addressed, either in a prospective or a retrospective fashion. The correlation between the RDI of systemic therapy and clinical outcomes has been demonstrated mainly for diffuse lymphoma [23-25] and metastatic solid tumours that are relatively sensitive to anti-tumour drugs [26-28]. In stage III CC, a retrospective study of 367 patients treated with fluoropyrimidine-based chemotherapy mainly without oxaliplatin between 2003 and 2008 at 19 VA medical centers in the USA showed an RDI of chemotherapy above $70 \%$, improving 5 -year OS [29]. It should be noted that in this study RDI was calculated for each drug within each regimen: i.e. 5fluorouracil, capecitabine and leucovorin [29]. One study directly evaluated the prognostic impact of oxaliplatin dose reduction in the adjuvant setting, but in stage II and III colorectal cancer [30]. In this study of South Korean patients it was observed that more than $60 \%$ of standard dose of oxaliplatin should be administered to achieve no difference in 5-year DFS and OS [30].

In our study of homogenous Caucasian stage III CC patients treated mainly with FOLFOX-4 $(N=336,92 \%)$, no relationship was found between numbers of cycles: $\leq 6$ vs. $>6$ cycles and DFS or OS. However, it should be observed that the majority of patients received more than 6 cycles of chemotherapy $(N=320,88 \%)$. Due to the oxaliplatin dose reduction in subsequent chemotherapy cycles, the median CD-O was $936.86 \mathrm{mg} / \mathrm{m}^{2}$, and in the group of patients who completed 12 cycles, 1012.33 $\mathrm{mg} / \mathrm{m}^{2}$. However, the CD-O in our group treated in clinical practice was higher compared to the doses in the MOSAIC and NASBP-C07 studies (respectively 810 and $677 \mathrm{mg} / \mathrm{m}^{2}$ ) but the clinical outcomes were slightly worse, with a 3-year DFS 61.64\% and median DFS 43,86 months [1-3]. The results in patients participating in clinical trials are generally better than in patients treated in everyday practice for a variety of reasons. However in our study, half of patients met the criteria of low-risk of relapse $(189,51.8 \%)$ but only 165 patients $(45.2 \%)$ in the whole cohort had at least twelve lymph nodes removed during surgery. The small number of examined nodes may be "under-staged" and affect the prognosis. However, some reports suggest that the total number of lymph nodes analyzed in stage III CC is not a prognostic indicator of cancer-specific and DFS [31, 32].

Among CC patients, $80 \%$ of recurrences become apparent within the first 3 years and an additional 15\% between the 3rd and 5th year of curative surgery [8-10, 33, 34]. Previous studies showed that stage III CC patients were more prevalent in the early-recurrence group than in the late-recurrence group, and had worse clinical outcomes $[8,10,11,35]$. In our study, the factors associated with early recurrence (within 18 months) were tumour grade, the number of positive and harvested lymph nodes, and RDI-O $<60 \%$. Interestingly, the risk of early recurrence in patients with RDI-O $<60 \%$ concerned the low-risk group in particular. These results should be referred to the aforementioned IDEA project and CAPOX efficacy in low-risk group [20-22]. It seems that RDI-O may be a more accurate reflection of the true patient-relevant benefit of adjuvant chemotherapy among stage III CC. However, patients with early recurrence showed worse overall survival regardless of the RDI-O.

We are aware that the retrospective nature of the study may have influenced our findings. Moreover, in our study we focused only on RDI-O not each drug within regimen and the risk of early recurrence. Further, we did not collect data on molecular abnormalities in primary tumour, e.g. the presence of activating mutations in the KRAS, NRAS and BRAF, or microsatellite instability and defective DNA mismatch repair (dMMR). However, previous research suggests that dMMR seems to be important only among stage II patients being considered for single-agent, fluoropyrimidine-based therapy [36]. Further research should focus on better biomarkers to assess the likelihood of chemotherapy response, based on molecular biology and pharmacokinetic analyses to reduce toxicity and improve treatment outcomes.

\section{Conclusions}

We have demonstrated that RDI-O under $60 \%$ in adjuvant setting among stage III CC patients apparently increases the likelihood of early recurrence, especially in the low-risk group. It should be noted that research into the optimal dose of oxaliplatin in adjuvant treatment is important, due to the lack of effective methods of prevention and therapy of long-term OXIPN, which negatively affects patients' quality of life [37].

\footnotetext{
Abbreviations

AEs: Adverse events; AJCC: American Joint Committee on Cancer; BMI: Body mass index; BRAF: Proto-oncogene, serine/threonine kinase; CAPOX/ XELOX: Chemotherapy schedule (oxaliplatin, capecitabin, leucovorin); CC: Colon cancer; CD: Cumulative dose; CEA: Carcinoembryonic antigen; CRC: Colorectal cancer; CTCAE: Common Terminology Criteria for Adverse Events; DDI: Delivered dose intensity; DFS: Disease-free survival; dMMR: Defective DNA mismatch repair; FOLFOX: Chemotherapy schedule (oxaliplatin, 5-fluorouracil, leucovorin); HR: Hazard ratio; IDEA: International Duration Evaluation of Adjuvant Chemotherapy collaboration; IQR: Interquartile range; IUCC: International Union for the Fight against Cancer; KRAS: Kristen rat sarcoma viral oncogene homolog;

MOSAIC: Multicenter International Study of oxaliplatin/5-fluorocil, Leucovorin in Adjuvant Treatment of Colon Cancer; NASBP-C07: National surgical Breast and Bowel Project; NCl: National Cancer Institute; NRAS: Neuroblastoma RAS viral oncogene homolog; OS: Overall survival; OXIPN: Oxaliplatin-induced peripheral neuropathy; R1: Microscopic tumour infiltrations; R2: Macroscopic tumour infiltrations; RDI: Relative dose intensity; RDI-O: Relative dose intensity of oxaliplatin; SDI: Standard dose intensity; STROBE: Strengthening the
} 
Reporting of Observational Studies in Epidemiology; TNM: TNM classification of Malignant Tumours

\section{Acknowledgments}

The authors wish to thank Mr. Artur Żok for graphics preparation and Prof. Ben Stanley for linguistic check.

\section{Authors' contributions}

Study concepts - J.Ż., R.D.; Study design - J.Ż., R.D., M.B.; Data acquisition J.Ż., R.D., B.R., M.B., J.K., K.A.; Quality control of data and algorithms - J.Ż., R.D., B.R., M.B., J.K., K.A.; Data analysis and interpretation - J.Ż., R.D., B.R., M.B., J.K., K.A.; Manuscript preparation - J.Ż., M.B., R.D.; Manuscript review - J.Ż., R.D., B.R., M.B., J.K., K.A. All authors have read and approved the manuscript.

\section{Funding}

The funding sources had no involvement in any of the followings: study design; the collection, analysis and interpretation of data; the writing of the report and the decision to submit the article for publication.

\section{Availability of data and materials}

The dataset used and analyzed in this study are not publicly available due to the data generated for the reporting but available only to the research members on reasonable request.

\section{Declarations}

Ethics approval and consent to participate

Bioethics Committee, Medical Chamber in Opole (Agreement No. 245/2017).

\section{Consent for publication}

Not applicable.

\section{Competing interests}

The authors declare that they have no competing interests.

\section{Author details}

${ }^{1}$ Department of Chemotherapy, Center of Pulmonology and Chemotherapy, 58-580 Szklarska Poręba, Poland. ${ }^{2}$ Department of Pathomorphology, Medical University of Gdańsk, 80-214 Gdańsk, Poland. ${ }^{3}$ Department of Oncology, Institute of Medical Science, University of Opole, 46-020 Opole, Poland. ${ }^{4}$ Department of Oncology, Military Institute of Medicine, 04-141 Warsaw, Poland. ${ }^{5}$ Department of Oncology, Regional Oncology Center, 80-210 Gdańsk, Poland.

Received: 14 June 2020 Accepted: 13 April 2021

Published online: 10 May 2021

\section{References}

1. André T, Boni C, Mounedji-Boudiaf L, Navarro M, Tabernero J, Hickish T, et al. Oxaliplatin, fluorouracil, and leucovorin as adjuvant treatment for colon cancer. N Engl J Med. 2004;350(23):2343-51. https://doi.org/10.1056/ NEJMoa032709.

2. André T, Boni C, Navarro M, Tabernero J, Hickish T, Topham C, et al. Improved overall survival with oxaliplatin, fluorouracil, and leucovorin as adjuvant treatment in stage II or III colon cancer in the MOSAIC trial. J Clin Oncol. 2009;27(19):3109-16. https://doi.org/10.1200/JCO.2008.20.6771.

3. Kuebler JP, Wieand HS, O'Connell MJ, Smith RE, Colangelo LH, Yothers G, et al. Oxaliplatin combined with weekly bolus fluorouracil and leucovorin as surgical adjuvant chemotherapy for stage II and III colon cancer: results from NSABP C-07. J Clin Oncol. 2007;25(16):2198-204. https://doi.org/10.12 00/JCO.2006.08.2974

4. Schmoll HJ, Tabernero J, Maround J, de Braud F, Price T, Van Cutsem E, et al. Capecitabine plus oxaliplatin compared with fluorouracil/folinic acid as adjuvant therapy for stage III colon cancer: final results of the N016968 randomized controlled phase III trial. J Clin Oncol. 2015:33(32):3733-40. https://doi.org/10.1200/JCO.2015.60.9107.

5. Haller DG, Tabernero J, Maroun J, de Braud F, Price T, Van Custem E, et al. Capecitabine plus oxaliplatin compared with fluorouracil and folinic acid as adjuvant therapy for stage III colon cancer. J Clin Oncol. 2011;29(11):146571. https://doi.org/10.1200/JCO.2010.33.6297.
6. Yothers G, O'Connell MJ, Allegra CJ, Kuebler JP, Colangelo LH, Petrelli NJ, et al. Oxaliplatin as adjuvant therapy for colon cancer: updated results of NSABP C-07 trial, including survival and subset analyses. J Clin Oncol. 2011; 29(28):3768-74. https://doi.org/10.1200/JCO.2011.36.4539.

7. Pectasides D, Karavasilis V, Papaxoinis G, Gourgioti G, Makatsoris T, Raptou $\mathrm{G}$, et al. Randomized phase III clinical trial comparing the combination of capecitabine and oxaliplatin (CAPOX) with the combination of 5fluorouracil, leucovorin and oxaliplatin (modified FOLFOX6) as adjuvant therapy in patients with operated high-risk stage II or stage III colorectal cancer. BMC Cancer. 2015;15:384.

8. Ryuk JP, Choi GS, Park JS, Kim HJ, Park SY, Yoon GS, et al. Predictive factors and the prognosis of recurrence of colorectal cancer within 2 years after curative resection. Ann Surg Treat Res. 2014;86(3):143-51. https://doi.org/1 0.4174/astr.2014.86.3.143

9. Renehan AG, Egger M, Saunders MP, O' Dwyer ST. Impact on survival of intensive follow up after curative resection for colorectal cancer: systematic review and meta-analysis of randomised trials. BMJ. 2002;324(7341):813.

10. Lan YT, Chang SC, Yang SH, Lin CC, Wang HS, Jiang JK, et al. Comparison of clinicopathological characteristics and prognosis between early and late recurrence after curative surgery for colorectal cancer. Am J Surg. 2014; 207(6):922-30. https://doi.org/10.1016/j.amjsurg.2013.08.035.

11. Sadahiro S, Suzuki T, Ishikawa K, Nakamura T, Tanaka Y, Masuda T, et al. Recurrence patterns after curative resection of colorectal cancer in patients followed for a minimum of ten years. Hepatogastroenterology. 2003;50(53): 1362-6.

12. Sobin LH, Gospodarowicz MK, Wittekind C. TNM classification of malignant tumours. 7th ed. England: Wiley-Blackwell; 2011. p. 100-6.

13. National Institutes of Health, Common Terminology Criteria for Adverse Events. https://www.eortc.be/services/doc/ctc/ctcae_4.03_2010-06-14_ quickreference_5x7.pdf Accessed 5 Feb 2010.

14. Vandenbroucke JP, von Elm E, Altman DG, Gøtzsche PC, Mulrow CD, Pocock SJ, et al. STROBE initiative. Strengthening the reporting of observational studies in epidemiology (STROBE): explanation and elaboration. Int I Surg. 2014;12(12):1500-24. https://doi.org/10.1016/j.ijsu.2014.07.014

15. Longo DL, Duffey PL, DeVita VT Jr, Wesley MN, Hubbard SM, Young RC. The calculation of actual or received dose intensity: a comparison of published methods. J Clin Oncol. 1991;9(11):2042-51. https://doi.org/10.1200/JCO.1991. 9.11.2042.

16. R Core Team. R: A Language and Environment for Statistical Computing; R Foundation for Statistical Computing. Vienna; 2020. https://www.R-project. org/. Accessed 1 Feb 2020

17. Dinno A. dunn. test: Dunn's Test of Multiple Comparisons Using Rank Sums, 2017. $R$ package version 1.3.5. https://CRAN.R-project.org/package=dunn.test Accessed 1 Feb 2020

18. Kassambara A, Kosinski M, Biecek P. survminer: Drawing Survival Curves using 'ggplot2'. 2019. R package version 0.4.6. https://CRAN.R-project.org/pa ckage=survminer. Accessed 1 Feb 2020

19. Tsai YJ, Lin JK, Chen WS, Jiang JK, Teng HW, Yen CC, et al. Adjuvant FOLFOX treatment for stage III colon cancer: how many cycles are enough? Springerplus. 2016;5(1):1318. https://doi.org/10.1186/s40064-016-2976-9.

20. Grothey A, Sobrero AF, Shields AF, Yoshino T, Paul J, Taieb J, et al. Duration of adjuvant chemotherapy for stage III Colon Cancer. N Engl J Med. 2018; 378(13):1177-88. https://doi.org/10.1056/NEJMoa1713709.

21. Shi Q, Sobrero AF, Shields AF, Yoshino T, Paul J, Taieb J, et al. Prospective pooled analysis of six phase III trials investigating duration of adjuvant oxaliplatin-based therapy (3 vs 6 months) for patients (pts) with stage III colon cancer (CC): The IDEA (International Duration Evaluation of Adjuvant chemotherapy) collaboration. J Clin Oncol. 2017;35:261 Suppl Abstract LBA1.

22. Sobrero AF, Andre T, Meyerhardt JA, Grothey A, Iveson T, Yoshino T, et al. Overall survival (OS) and long-term disease-free survival (DFS) of three versus six months of adjuvant (adj) oxaliplatin and fluoropyrimidine-based therapy for patients (pts) with stage III colon cancer (CC): Final results from the IDEA (International Duration Evaluation of Adj chemotherapy) collaboration. J Clin Oncol. 2020;38:4004.

23. Epelbaum R, Haim N, Ben-Shahar M, Ron Y, Cohen Y. Dose-intensity analysis for CHOP chemotherapy in diffuse aggressive large cell lymphoma. Isr J Med Sci. 1988;24(9-10):533-8.

24. Pettengell $\mathrm{R}$, Schwenkglenks M, Bosly A. Association of reduced relative dose intensity and survival in lymphoma patients receiving CHOP-21 chemotherapy. Ann Hematol. 2008;87(5):429-30. https://doi.org/10.1007/ s00277-008-0447-2. 
25. Bosly A, Bron D, Van Hoof A, De Bock R, Berneman Z, Ferrant A, et al. Achievement of optimal average relative dose intensity and correlation with survival in diffuse large B-cell lymphoma patients treated with CHOP. Ann Hematol. 2008;87(4):277-83. https://doi.org/10.1007/s00277-007-0399-y.

26. Berardi R, Torniai M, Pusceddu S, Spada F, Ibrahim T, Brizzi MP, et al. Prognostic impact of the cumulative dose and dose intensity of everolimus in patients with pancreatic neuroendocrine tumors. Cancer Med. 2017;6(7): 1493-9. https://doi.org/10.1002/cam4.1028.

27. Tjan-Heijnen VC, Wagener DJ, Postmus PE. An analysis of chemotherapy dose and dose-intensity in small-cell lung cancer: lessons to be drawn. Ann Oncol. 2002;13(10):1519-30. https://doi.org/10.1093/annonc/mdf249.

28. Loibl S, Skacel T, Nekljudova V, Lück HJ, Schwenkglenks M, Brodowicz T, et al. Evaluating the impact of relative Total dose intensity (RTDI) on patients' short and long-term outcome in taxane- and anthracycline-based chemotherapy of metastatic breast cancer - a pooled analysis. BMC Cancer. 2011;11(1):131. https://doi.org/10.1186/1471-2407-11-131.

29. Aspinall SL, Good CB, Zhao X, Cunningham FE, Heron BB, Geraci M, et al. Adjuvant chemotherapy for stage III colon cancer: relative dose intensity and survival among veterans. BMC Cancer. 2015;15(1):62. https://doi.org/1 0.1186/s12885-015-1038-y.

30. Park D, Baek SJ, Kwak JM, Kim J, Kim SH. Analysis of reduced-dose administration of oxaliplatin as adjuvant FOLFOX chemotherapy for colorectal cancer. Ann Surg Treat Res. 2018;94(4):196-202. https://doi.org/1 0.4174/astr.2018.94.4.196.

31. Tsikitis VL, Larson DL, Wolff BG, Kennedy G, Diehl N, Qin R, et al. Survival in stage III colon cancer is independent of the total number of lymph nodes retrieved. J Am Coll Surg. 2009;208(1):42-7. https://doi.org/10.1016/j.ja mcollsurg.2008.10.013.

32. Prandi M, Lionetto R, Bini A, Francioni G, Accarpio G, Anfossi A, et al. Prognostic evaluation of stage $B$ colon cancer patients is improved by an adequate lymphadenectomy: results of a secondary analysis of a large scale adjuvant trial. Ann Surg. 2002;235(4):458-63. https://doi.org/10.1097/ 00000658-200204000-00002.

33. Sargent DJ, Wieand HS, Haller DG, Gray R, Benedetti JK, Buyse M, et al. Disease-free survival versus overall survival as a primary end point for adjuvant colon cancer studies: individual patient data from 20,898 patients on 18 randomized trials. J Clin Oncol. 2005;23(34):8664-70. https://doi.org/1 0.1200/JCO.2005.01.6071.

34. Sargent D, Sobrero A, Grothey A, O'Connell MJ, Buyse M, Andre T, et al. Evidence for cure by adjuvant therapy in colon cancer: observations based on individual patient data from 20,898 patients on 18 randomized trials. J Clin Oncol. 2009;27(6):872-7. https://doi.org/10.1200/JCO.2008.19.5362.

35. O'Connell MJ, Campbell ME, Goldberg RM, Grothey A, Seitz JF, Benedetti JK, et al. Survival following recurrence in stage II and III colon cancer: findings from the ACCENT data set. J Clin Oncol. 2008;26(14):2336-41. https://doi. org/10.1200/JCO.2007.15.8261.

36. Sargent DJ, Marsoni S, Monges G, Thibodeau SN, Labianca R, Hamilton SR, et al. Defective mismatch repair as a predictive marker for lack of efficacy of fluorouracil-based adjuvant therapy in colon cancer. J Clin Oncol. 2010; 28(20):3219-26. https://doi.org/10.1200/JCO.2009.27.1825.

37. Zedan AH, Hansen TF, Fex Svenningsen A, Vilholm OJ. Oxaliplatin-induced neuropathy in colorectal cancer: many questions with few answers. Clin Colorectal Cancer. 2014;13(2):73-80. https://doi.org/10.1016/j.clcc.2013.11. 004.

\section{Publisher's Note}

Springer Nature remains neutral with regard to jurisdictional claims in published maps and institutional affiliations.

Ready to submit your research? Choose BMC and benefit from:
- fast, convenient online submission
- thorough peer review by experienced researchers in your field
- rapid publication on acceptance
- support for research data, including large and complex data types
- gold Open Access which fosters wider collaboration and increased citations
- maximum visibility for your research: over 100M website views per year
At BMC, research is always in progress.
Learn more biomedcentral.com/submissions

